\title{
高职院校专业群建设项目管理机制研究
}

\author{
蔡春娥 \\ 泉州华光职业学院 \\ DOI : 10.32629/mef.v2i12.506
}

[摘 要] 专业群建设立足应用工科和现代生产性服务为主的专业布局, 充分运用区域经济产业的优势, 促进行业、企业参 与职业教育人才培养全过程。针对专业群建设管理具备完整的生命周期和项目管理的过程性, 并具有项目管理的特点。高职 院校必须规范专业集群化建设，才能使专业嵌入产业链，用完整的专业群对接产业链，培养出高素质技术技能人才。

[关键词] 专业群; 建设项目; 管理; 机制

\section{Research on Project Management Mechanism of Professional Group Construction in Higher Vocational Colleges}

\section{Cai Chun'e}

\section{Quanzhou Huaguang Vocational College}

[Abstract] The construction of professional groups is based on the professional layout based on applied engineering and modern productive services, making full use of the advantages of regional economic industries, and promoting the participation of industries and enterprises in the entire process of vocational education personnel training. Construction management for professional groups has a complete life cycle and project management process, and has the characteristics of project management. Higher vocational colleges must standardize the construction of professional clusters in order to embed specialties in the industrial chain, use a complete professional group to dock the industrial chain, and cultivate high-quality technical and skilled personnel.

[Keywords] professional group; construction project; management; mechanism

高职专业群是以校企合作、产教融合为基础, 紧密开展 “双主体”协同育人为目标的建设项目，专业群建设项目管 理具有项目管理的过程性, 拥有一个完整的生命周期; 是一 个包含项目启动阶段、计划阶段、实施控制阶段、收尾阶段 等完整的、系统的项目管理过程。而且在整个专业群建设生 命周期中, 要求为了实现专业群建设的项目目标, 制定项目 计划、分解工作任务、安排预算和资源, 对项目所需时间、 实时进度、投入成本、监控质量、隐显风险等诸多方面采取 必要的协调、管理和控制手段, 通过项目管理的方法对资源 的优化配置来实现专业群建设收益的最大化。

高职院校一般意义上的职能式管理模式已经不适应专 业群建设这一现代职业教育建设项目需要。本文将项目过程 管理实践, 用来解决专业群建设项目在管理、实施过程中遇 到的人员短缺、经费使用困难、横向协调不足、分项目进度 滞后、质量标准不明确等问题; 另一方面要通过分析、归纳 项目管理方法在专业群建设中应用的广度、深度和效度。本 文通过三年专业群建设实践, 研究构建了专业群建设项目管 理机制, 能对同类院校专业群项目管理工作起到借鉴作用。

\section{1 共建共引共管共享机制}

构建以优势专业为核心的专业群发展机制, 立足区域经 济社会发展的实际, 特别是产业转型升级路线动态调整专业 结构和培养方向, 实施 “应用-实用-拓展” 专业群建设梯度,
聚焦产教融合, 多方协同共建共享标准体系, 共引共享双元 双师团队，形成共研共管的保障机制。

\section{1共研共建专业标准}

建全校企协同育人机制, 提高学生的岗位适应能力, 开 发体现工学结合教、学、做一体化特色的课程体系。融合 “ $1+X$ ” 证书制度试点, 推进校企全要素合作, 引进行业企 业岗位职业标准, 对接行业最新技术, 按 “项目驱动、教学 做合一”的原则, 校企共同开发高新技术和科技研发实训课 程, 以及职业技术等级证书培训课程。

充分发挥专业群课程相互交叉的知识与技能, 模块课程 对接区域产业, 关联性强、辐射面广的智能化及高新技术岗 位。以 “产教融合、技师指导、企业实战、多能实践” 的作 品转化产品的特色课程体系, 使实践与理论融通, 提高了学 生的动脑能力、动手能力和创新能力, 让 “差异化” 的学生 在课程中寻找自己的 “个性化”, 为自己寻找适合的 “岗位 技能”。

1. 2 互聘共享双师团队

健全专兼职教师互聘下车间、进课堂实践的德技并修机 制。改革单一的书本教学模式, 直接融入专业理论教学 + 企 业产品研发+智能化及高新技术的三大模块教学方式。专业 教师根据本人专长和承担的教学任务, 在寒暑假期间, 接受 企业聘请进车间或研发部, 参与作品转化产品开发或横向课 
题研究, 并承担企业员工文化培训任务。

企业技师进课堂，将自己在生产一线积累的岗位技能， 通过描述或直观演示让学生看清每个技能动作的各个环节。 学生通过自己的操作来实践技师的示范动作, 从而掌握复杂 的操作过程。同时将流行趋势的产品作为实践教学项目引入 课堂, 突破书本对作品设计的条框, 紧贴产品造型及功能设 计的界限。企业技师运用实战的设计研发技术, 以企业生产 样品为教学案例, 融合创新创业教育与实践, 激发学生对作 品转化产品的兴趣与成就。

专业教师与企业技师联合成立《技能大师工作室、创业 导师工作室》通过互聘共享开展教学与技术指导, 横向课题 应用研究, 形成实战双师团队, 为技术创新、专利设计、教 学改革提供服务平台。

\section{3共建共管长效机制}

加强多方联动协同保障, 立足产教融合大平台、省级行 指委、职业院校联盟等平台优势, 发挥企业代表在学术委员 会、专业建设委员会、教材选用委员会等机构的作用, 强化 多元参与办学主体建设, 推进多元共治, 不断健全制度保障, 建立可持续发展的专业群建设保障机制, 确保专业群高质量 运行。

\section{2 专业群可持续发展机制}

2. 1专业群良性发展一要依据国家职业标准和企业用人 标准, 将 “企业文化” 引入课堂, 强化职业素养教育教学, 建设专业群通用的职业素养课程体系与教学模式。二要对接 行业最新技术, 按 “项目驱动、教学做合一” 的原则, 校企 共同开发高新技术实训项目和科技研发等高新技术课程，应 对企业发展对高新技术人才的需求。三要完善智能化生产线 建设与应用。建设专业教学资源库, 校企合作开发信息化教 学课程和信息化学习平台, 实现信息化教学资源开放服务于 社会。四要搭建教师与技师共同成长平台, 鼓励教师到企业 去 “应聘”，承担企业员工继续教育任务，参与企业技术研 发等活动, 提升教学水平和技术服务能力。创造条件促使企 业技师 “应聘” 为学校的技能大师, 把先进的行业高端技术 融入教学环节。共同承担纵向与横向科研课题研究与应用; 共同开发学生作品与学校师生的专利产品。

2. 2 建立专业评价机制, 以第三方对学校各专业人才培 养质量、就业质量、创新创业质量等数据为评价依据, 对应 现有专业实施 “红黄绿” 制度, 完善专业预警机制, 以产业 结构调整和新经济增长点为标准, 支持发展 “绿牌” 专业, 调整改造 “黄牌” 专业, 撤销关停 “红牌” 专业, 使人才培 养供给侧跑赢企业用人需求端。

2.3 专业群校企共建发展机制。密切跟踪新技术、新模 式、新业态, 对接未来产业变革和技术进步趋势, 瞄准对接 区域产业链需求, 以适度超前为原则, 立足现实需求, 调整 人才培养定位, 更新教学内容, 将新技术、新工艺、新规范 等产业先进元素纳入教学标准和教学内容, 推动相关资源共 建共享, 形成错位发展、优势互补的专业群发展格局。校企
合作开展工学结合的多元实训高新技术课程由企业提供实 验项目，专业教师、企业技师和学生同在实验室或在链接的 企业技术部门完成教学任务, 形成 “以项目驱动过程, 产学 研一体化” 的直接培养方法。并结合学生个性化培养和小班 教学, 提高了课程对接职业岗位的针对性、实用性, 促进了 学生高层次就业。

基于专业群的特点，按全技术领域、全产业链、全集群 化等角度构建专业群发展机制, 有效保障专业群良性发展。 确保培养目标适应岗位要求、教学内容体现主流技术, 人才 培养体系与时俱进。

2. 4信息化教学与服务机制。不断推进教学资源建设任 务。以信息化教学平台为依托, 依据专业建设需求, 新增 网络课程、微课、企业案例和课程知识点等资源建设任务。 同时，信息化教学平台将立足校内，服务兄弟高校及合作 企业, 为兄弟院校学生开展跨校选修课学习、合作企业员 工开展远程教育培训提供服务。引入硕博士论文数据库、 维普中文期刊服务平台、万方知识服务平台、高等教育应 用资源服务平台、尚唯外文科技报告等电子刊物, 满足师 生专业拓展和科技创新需要。同时, 专业群明确考核和激 励措施, 促进教师使用信息化手段来开展教育教学、科研 工作，以保证课程资源得到实时的动态更新，进而保证资 源的有效性和先进性。

2.5学生工作信息化管理机制。依托信息化水平的提升, 进一步推进学生管理资源的有效配置, 提高学生管理工作质 量和管理水平, 快速了解学生学习状态和未来发展动向, 使 学生管理工作队伍从重复而繁杂的事务性工作中解脱出来。 以网络为平台细化学生工作指标, 着力构建学生基本信息数 据库和学生管理工作数据库, 利用网络技术、服务器和数据 库管理实现 $\mathrm{B} / \mathrm{S}$ 三层架构, 并通过动态管理, 努力构建学生 管理工作者与学生在常规管理、校园文化建设、学生政治思 想认识、职业生涯规划等方面交流、沟通与反馈的平台, 通 过信息化来提高学生管理工作效率, 优化学生管理工作的育 人目的。

\section{3 专业群建设保障机制}

职业院校建立健全专业群建设的各项制度和项目管理 制度，确保项目建设顺利推进。制定专业群项目建设相关管 理办法，明确管理机构与职责、建设实施与督查、资金管理、 考核与奖励、罚则等, 确保项目建设顺利进行。

3.1协同推进机制

3. 1. 1成立专业群建设工作领导小组。负责组织协调指 挥, 负责项目建设的组织实施工作。下设专业群建设办公室。 设置政策研究、项目管理、质量控制三 个工作组，负责项 目建设研究、项目任务申报、任务计划落实、项目任务考核、 内部质量控制等工作。加强服务产业特色专业群建设的组织 领导, 建立专业群建设工作班子, 明确项目建设的责任人, 做到分工明确、责任落实。

3.1.2完善专业群校企共建委员会。搭建地方政府、地 
方龙头骨干企业与学校的协商合作平台, 形成学校与利益相 关方合作办学、合作育人、合作就业、合作发展的长效机制, 实现专业群建设的科学决策、民主监督和社会参与。

3. 2 项目实施管理机制

3. 2.1 编制《职业学院专业群建设申报书》《职业学院专 业群建设方案》, 指导项目具体实施。确定各建设项目具体 责任人，将目标责任制落实到每个具体建设部门。

3.2.2制定《职业学院专业群建设项目管理与绩效考核 办法》, 明确建设项目的目标、责任, 对建设过程进行监督 和定期考核。

3.2 .3 制定《职业学院专业群建设项目专项资金管理办 法》，保障建设资金合法合规安排、有效利用。

3. 2.4 以信息公开制实现全程监控。在学校主页设立“特 色专业群建设专栏”, 向社会各界、师生员工公开项目进展 和资金使用情况，接受有关部门的监督、监察和审计。

3.3 健全多元投入机制

按照专业群建设要求, 统筹项目建设经费预算总额。学 校将多渠道筹措资金确保经费保障, 包括: 省财政支持、地 方财政划拨专项建设经费、行业企业投入和学校自筹等。多 方筹措资金，加大重点专业群的投入。

3. 4 改革发展机制

认真贯彻党和国家的教育方针和职业教育系列文件精 神, 明确职业教育办学方向, 明晰改革发展思路, 以建设专 业群为契机, 树立精品意识和质量意识, 形成人人关心教育 质量、人人为专业群建设做贡献的良好校园氛围, 最大限度 地激发全体师生的创造力和活力, 助力学校高质量发展。

\section{4 专业群项目的控制管理}

专业群项目控制主要包括项目范围的控制、项目成本的 管理、项目进度和质量的控制, 并且以专业群的质量管理为 控制重点。

4. 1 项目计划管理。专业群建设项目计划的制定要求去 发现、整理、汇总学院现有的可用的专业建设资源, 再科学 地安排专业群项目资金, 制定科学合理的项目建设预算计 划; 将专业群建设项目进行必要有效的工作分解, 做好项目 工作分解计划; 执行项目进度计划, 保证项目执行过程中有 规可循。

4. 2 项目实施管理。把专业群建设作为一个项目来管理, 要求对实施项目的每一个阶段具体进度和该项目完成的最 终期限进行确定, 同时也要认真制定项目的进度计划, 并且 严格执行项目进度。专业群建设项目的进度计划有项目总体
进度计划和分阶段进度计划两种。其中, 总体进度计划就是 以专业群建设目的规模和复杂性、工作任务特点等列出关键 可交付成果以及各关键成果交付时间以及最终完成项目的 时间。而阶段进度安排则从具体的、详细的角度安排项目的 进度信息。

4. 3 质量控制管理。专业群建设项目质量控制主要由两 部分组成: 一部分是监督和考核专业群建设项目整体、各 子项目的质量, 这方面的质量控制要求负责人事先进行《项 目质量计划书》的编写制定, 并指定特定的人负责跟踪和 管理。第二部分就是需要构建起完善、科学、合理的评价 指标体系, 将专业群建设的资源整盒、构建所创造的价值 进行量化考核。

对于专业群建设项目来说, 项目范围控制重点是要求学 校加强对专业群建设项目计划书所属范围的监督调整。专业 群项目过程管理中, 要加强对项目参与者和专业资源动态变 化的监督和把控。把握的原则是有利于提升专业建设质量、 有利于在计划进度内完成项目目标。

\section{5 结语}

高职院校专业群建设项目是一个结合了知识、创新、实 践、管理于一体的项目，也是相对复杂的、多系统的项目。 项目的建过程中，将项目分解成多个子项目，而又安排不同 的人进行子项目的管理，这导致的后果是项目成员面对面交 流的机会大大减少了, 而这很有可能将对项目的整体完成质 量造成影响。因此，构建及时性、高效性、完整性的项目管 理机制体系，以合理的方式产生、收集、传播、保存和交流 项目信息，有助于学校、企业和政府在专业群建设实施过程 中相互配合, 相互协调和沟通; 有助于项目管理小组及时掌 握创新创业教育项目的实时情况，并且实现良好的质量控 制、进度管理、风险管理，成本控制，促进全过程信息的及 时流通。

\section{[参考文献]}

[1]崔岩.创新高水平专业群建设路径 [N].中国教育 报,2019-05.

[2]涨红.高职院校高水平专业群建设路径选择[J].中国 高教研究,2019(06):105-108.

[3]王爱社.高职院校特色专业及专业群建设的研究[J]. 陕西教育(高教版),2017(10):70+74.

\section{作者简介：}

蔡春娥 ( 1985-- ), 女, 汉族, 福建泉州人, 助理研究 员，硕士，研究方向：项目管理。 